\title{
Regional food dishes in the Brazilian National School Food Program: Acceptability and nutritional composition
}

\author{
Preparações regionais no Programa Nacional \\ de Alimentação Escolar: aceitabilidade \\ e composição nutricional
}

Diogo Thimoteo DA CUNHA ${ }^{1}$

Hélida Ventura Barbosa GONÇALVES'

Aline Fátima Andrade DE LIMA

Paula Andrea MARTINS ${ }^{3}$

Veridiana Vera DE ROSSO'

Elke STEDEFELDT²

A B S T R A C T

\section{Objective}

The objective of this study was to evaluate the nutritional composition and describe the acceptability of regional culinary dishes served to students from public schools of rural and urban areas.

\section{Methods}

Ten Brazilian regional dishes were evaluated for acceptability and nutritional composition. The survey was conducted in schools located in rural and urban areas of two cities in the state of São Paulo. Dish acceptability was evaluated using leftover analysis and a 5-point facial hedonic scale. The adherence index was calculated and used as an indirect measure of acceptance, and the nutritional composition was calculated based on the technical files of each dish.

\section{Results}

A total of 2,384 students from 20 schools participated in the study and 1,174 tasted and evaluated the dishes. The test using the 5-point facial hedonic scale demonstrated that five dishes (Caldo verde soup, persimmon

\footnotetext{
${ }^{1}$ Universidade Federal de São Paulo, Departamento de Biociências, Grupo de Estudo em Qualidade de Alimentos. Santos, SP, Brasil.

2 Universidade Federal de São Paulo, Departamento de Gestão e Cuidados em Saúde, Grupo de Estudo em Qualidade de Alimentos. R. Silva Jardim, 136, Vila Mathias, 11015-020, Santos, SP, Brasil. Correspondência para/Correspondence to: E STEDEFELDT. E-mail: <elke_nutri@hotmail.com>.

${ }^{3}$ Universidade Federal de São Paulo, Departamento de Ciências do Movimento Humano, Laboratório de Epidemiologia Nutricional. Santos, SP, Brasil.

Support: Fundo Nacional de Desenvolvimento da Educação (Process nº 1236110610509105).
} 
jelly, chicken with okra, puréed cornmeal with spinach, and arugula pizza) had an acceptability rate above $85.0 \%$. The mean adherence indices were $57.3 \%$ and $55.6 \%$ in urban and rural environments, respectively. Analysis of the nutritional composition of regional dishes indicates that these dishes can partially meet macronutrient recommendations.

\section{Conclusion}

The tested dishes can become part of school menus as they were accepted or partly accepted by the students regardless of school location, whether rural or urban. The cultural heritage is an important resource for the food sovereignty of a country and should be constantly encouraged.

Indexing terms: Food habits. Nutrition programs and policies. Public policies. School food.

\section{RE S U M O}

\section{Objetivo}

Avaliar a composição nutricional e descrever a aceitabilidade de preparações regionais servidas aos estudantes de escolas públicas de áreas rurais e urbanas.

\section{Métodos}

Dez preparações regionais brasileiras foram avaliadas quanto à aceitabilidade e à composição nutricional. A pesquisa foi realizada em escolas localizadas em áreas rurais e urbanas de duas cidades no estado de São Paulo. A aceitabilidade dos alimentos foi avaliada por meio da análise de restos e da escala hedônica facial de 5 pontos. O índice de adesão foi calculado e utilizado como medida indireta da aceitação. A composição nutricional foi calculada com base nas fichas técnicas de cada prato.

\section{Resultados}

Participaram do estudo 2384 estudantes de 20 escolas públicas; destes, 1174 provaram e avaliaram os pratos. A avaliação por meio da escala hedônica facial de 5 pontos demonstrou que cinco pratos (caldo verde, geleia de caqui, frango com quiabo, angu com espinafre e pizza de rúcula) tiveram um percentual de aceitabilidade acima de 85,0\%. O percentual médio de adesão à alimentação escolar foi de 57,3\% e 55,6\% em escolas urbanas e rurais respectivamente. A análise da composição nutricional das preparações regionais indicou que os pratos testados podem ser fontes de vários micronutrientes e atender parcialmente as recomendações de macronutrientes exigidas pela legislação.

\section{Conclusão}

Os pratos testados podem tornar-se parte do cardápio escolar, pois foram aceitos ou parcialmente aceitos pelos alunos, independentemente da localidade da escola. O patrimônio cultural é um recurso importante para a soberania alimentar de um país e deve ser constantemente estimulado.

Termos de Indexação: Hábitos alimentares. Políticas públicas. Programas e políticas de nutrição e alimentação. Alimentação escolar.

\section{N T R O D U C T IO N}

The development of eating habits starts in pre-school and will reflect directly on children's growth and development ${ }^{1}$. Therefore, being aware of what is offered and how food choices are made during this phase of life are important, since eating habits incorporated in this phase will influence health in adulthood ${ }^{1,2}$. Associated with family and environmental factors, the school has a key role in forming healthy eating habits because in school the child can acquire autonomy over what he or she eats primarily if associated with nutrition education programs ${ }^{1}$.

The Programa Nacional de Alimentação Escolar (PNAE, National School Food Program) is characterized as one of the longest-lasting public policies in Brazil. It constitutes an important strategy for food and nutrition security, while promoting the "Human Right to Adequate Food"3,4. It ensures permanent and continuous 
access to quality foods and in adequate quantity without compromising other essential needs.

This policy covers 45.6 million students enrolled in basic education of the public networks of Brazil every day of the year ${ }^{4}$. One goal of the program is to provide free food to students, ensuring at least $20 \%$ of the students' daily nutritional needs, with a variety of foods prioritizing the children's dietary adherence and acceptability ${ }^{5,6}$. It also seeks to prioritize respect for eating habits and the regional produce in order to promote local development ${ }^{5,7}$. The incorporation of regional dishes in school menus can contribute to the preservation of the Brazilian food culture, bearing in mind the magnitude of the program.

Therefore, it is possible to unify two major aspects of this program, a healthy and adequate diet with respect to regional habits, mainly because most regional dishes involve fruits and vegetables $^{8}$. Despite the legal requirement that menus of school food programs must meet the local nutritional references, eating habits, food culture, and tradition ${ }^{7}$, a significant number of school food menus does not include regional foods, particularly in the country's North and Midwest regions ${ }^{9}$. Additionally, the menus in large Southern capitals contained few regional food items or regional dishes ${ }^{10}$.

Appreciation for dietary practices based on local characteristics and traditional foods has increased because the process of globalization is characterized by homogenization and standardization in various orders ${ }^{11}$; however, this appreciation seems to be little explored by states and municipalities. The insertion of regional foods and regional dishes in school food programs can promote the local cultural identity and improve the acceptability of the menus ${ }^{10}$.

Acceptability is therefore an important indicator for assessing and deciding whether these preparations should compose the menu of school meals.

Tests of acceptance of meals offered in schools are required by federal law ${ }^{5}$ and are important instruments for verifying how the dietary habits and preferences of the students are ensured by the school meals.

Few studies address issues related to school food and food culture, and none directly assesses the acceptance of regional dishes in this environment. In this context the objective of this study was to evaluate the nutritional composition and describe the acceptability of regional dishes served to students in rural and urban areas. These data will essentially contribute to the eating habits of these communities as well as determine which foods should be introduced to the menus in order to enhance regional culture and encourage nutrient intake.

\section{METHOD S}

This cross-sectional, descriptive study was conducted from February to December 2009 and included 20 public schools. The inclusion criteria were: second to fifth graders of either gender aged seven to ten years attending a public school in one of two Brazilian municipalities located in the Southeast region of the country. The schools had no canteens selling food, a factor that demonstrably affects adherence and acceptability of school meals ${ }^{12}$.

We used simple random sampling. One hundred students were enrolled for each dish test, which was sufficient considering absences and refusals. These students were selected randomly from the six study schools, three urban and three rural. Sample size determination was based on guidelines in Bartlett et al. ${ }^{13}$ and calculated using Cochran's ${ }^{14}$ method, assuming a 5\% alpha level (type I error), a 3\% margin of error, and two regions in each municipality: urban and rural ${ }^{15}$.

\section{Regional dishes}

The following ten regional dishes from the Brazilian Southeast, where the study was conducted, were evaluated in the schools: 1) puréed cornmeal with spinach (cornmeal mixed 
in a blender with water, cooked with spinach); 2) star fruit cake (dish based on wheat flour, egg, milk, or water, oil or margarine, yeast, sugar, and puréed star fruit, decorated with pieces of star fruit); 3) rice pudding with mango (rice cooked in milk and sugar to which mango pieces and cinnamon are added); 4) jackfruit conserve (seedless jackfruit segments with added sugar, water, lemon juice, and spices, such as cloves and cinnamon); 5) arugula pizza (disc of fermented flour dough, sprinkled with tomato sauce and topped with cheese and arugula); 6) green beans and corn flour (stir fried green beans mixed with corn flour); 7) kale with garlic (kale cut into thin strips stir fried with garlic and olive oil); 8) chicken with okra (chicken cooked with seasonings and spices plus okra); 9) caldo verde soup (green broth - creamy potato broth to which finely sliced cooked kale, seasonings, and pepperoni are added); 10) persimmon jelly (persimmon pulp mixed in blender and cooked with sugar and lemon juice).

The main ingredients of the selected dishes are present in the guidelines of the regional food guide of the Brazilian Ministry of Health ${ }^{8}$ to promote the dissemination of Brazilian fruits and vegetables.

All study dishes were selected based on the results of a survey conducted by the Brazilian Ministry of Health. According to these results, all the chosen dishes were frequently consumed in the Southeast region. The recipes will be part of the second edition of the "Brazilian Regional Food Guide".

Caldo verde soup and arugula pizza were served as complete meals without any supplement. For the other dishes, a vehicle or supplement was served approaching the dishes to the reality of the school food. The dishes puréed cornmeal with spinach, green beans and corn flour, and kale with garlic were offered with rice, beans and meat. Chicken with okra was served with rice and beans. Persimmon jelly was served with cream-cracker biscuit. The other dishes are fruit-based desserts that followed a meal consisting of one kind of cereal, one vegetable, and meat.

These dishes were prepared and tested previously in the Laboratory of Dietetic Techniques of Universidade de Brasilia to create a detailed technical file containing: ingredients, quantity of each ingredient, yield, and nutritional value and portion (carbohydrates, proteins and lipids). The dishes were also chosen based on highly consumed ingredients in the Southeast ${ }^{16}$ at an affordable cost, and all dishes needed to have, on their list of ingredients, at least one fruit or vegetable.

In the school all dishes were prepared by school food handlers. The researchers assisted food handlers during the preparation to make sure they followed the recipe correctly. All the ingredients were weighed using a digital scale.

The portions of food served to each student were standardized. These portions were appropriate to the students' ages and served as customary.

\section{Evaluation of acceptance of regional dishes}

The researchers administered the questionnaires, collected data, and assisted the food handlers during food preparation.

Two methods were used to evaluate the acceptance of regional dishes: Leftover analysis and the 5-point facial hedonic scale. These two tests are recommended for this purpose by the Brazilian legislation?

\section{Test 1: Leftover analysis}

Leftover analysis was based on the method described by Abreu et al. ${ }^{17}$, by calculating the percentages of rejection and acceptance. The method uses equations 1 and 2 below to find the rejection and acceptance percentages: 
(equation 1)

Rejection percentage $=\frac{(\text { weight of the meal rejected } \times 100)}{\text { weight of distributed meal }}$

(equation 2)

Acceptance percentage $=100$ - Rejection percentage

The weight of the food that has been rejected and left on the plate is considered the rejected meal; the distributed meal is the weight of the meal produced minus that one which was not served to the student. For this test we used a scale with a maximum capacity of 20 kilograms and an accuracy of 10 grams.

\section{Test 2: 5-point facial hedonic scale using a form}

The 5-point facial hedonic scale used in the study was described by Lawless \& Heymann ${ }^{18}$ and da Cunha et al. ${ }^{19}$. The mixed 5-point facial hedonic scale ${ }^{4}$ with five faces was used, representing the categories: "hated it," "disliked it," "indifferent," "liked it," and "loved it" with the corresponding numbers 1-5. The student was asked to fill in a form indicating the degree of satisfaction regarding the study dish, as recommended by the Brazilian legislation ${ }^{5}$. The categorical scale was dichotomized to calculate the percentage of acceptance. The hedonic scale scores 1, 2, and 3 were grouped together, categorizing this region of the scale as a rejection area, and the scores 4 and 5, regarding the hedonic terms "liked" and "loved", were grouped together, corresponding to the acceptance area of the scale. Then the percentage of students who accepted each dish was calculated and compared with the cut-offs established by the National School Food Program regulation: acceptability $\geq 85 \%$ using the hedonic scale method and $\geq 90 \%$ using the leftover analysis to consider the dish accepted $^{5,19}$.

The study dishes were classified into five categories based on the acceptability rate given by the 5-point facial hedonic scale and leftover analysis, as follows: if the acceptability rate ranged from 0 to $19.9 \%$ - the students "hated the meal"; 20.0 to $39.9 \%$ - "disliked it"; 40.0 to $59.9 \%$-"indifferent"; 60.0 to $79.9 \%$ - "liked it"; and 80.0 to $100.0 \%$-"loved it".

Dishes classified as "liked it" and/or "loved it" were deemed accepted by the students.

Dietary adherence by the students to the study dishes was also determined. This datum provides complementary information to the tests of acceptability and leftovers.

\section{Adherence index}

The adherence index included a calculation to see how many students ate on the day the dish was served, an indirect measure of acceptance of dishes served as shown in equation 3.

(equation 3)

Adherence

Index $=\frac{\text { (number of students who consumed the meal } x \text { 100) }}{\text { number of students in school }}$

The researchers tried not to call the attention of the students to the research in order to leave them at ease and not to interfere on the adherence index.

\section{Data analysis}

The technical files of the preparations were used for counting the nutrients and energy content of each study dish. The study nutrients were: carbohydrates (g) protein (g), lipids (g), fiber (g), retinol (mcg), ascorbic acid (mg), iron (mg), calcium (mg), magnesium (mg), and zinc (mg). For all nutrients, the adequacy for the study age group was given by the nutritional recommendations of the current program ${ }^{5}$, based on the recommendations of the Dietary Recommended Intake ${ }^{20}$. The software Avanutri Online ${ }^{\circledR}$ calculated the nutrients and energy content of the study dishes only. The nutritional composition of the accompaniments was not included in this calculation.

Contingency tables with the outcome accept/reject were prepared to determine 
differences in acceptability and adherence between the school children of urban and rural areas, and the Chi-square test with Yates correction or Fisher's exact test for values lower than five were used.

We calculated the correlation between the acceptability values obtained in the 5-point facial hedonic scale and leftover analysis. For these calculations, we used the intra-class correlation coefficient. The Spearman correlation test investigated the relationship between the adherence results and acceptability measures.

Data were analyzed using the software Statistical Package for the Social Sciences (SPSS) 15.021 and, in all tests, $p<0.05$ was considered significant.

The project was approved by Universidade Federal de São Paulo's Research Ethics Committee under Protocol nº 0307/08 on March 14, 2008, and all parents or children's guardians signed an Informed Consent Form.

\section{RESULTS AND DISCUSSION}

A total of 2,384 students from 20 schools participated in the study and of these 1,174 tasted and evaluated the dishes using the 5-point facial hedonic scale.

Table 1 shows the nutritional composition of the study dishes. The dishes provided a diverse amount of essential nutrients for the dietary requirements and nutrition of school children in this age group.

The following four study dishes were served with accompaniments: puréed cornmeal with spinach, green beans and corn flour, kale with garlic, and chicken with okra. They were served with rice and beans. The combination of cereal and legume, most commonly rice and beans, is also part of the Brazilian food tradition. In a study conducted in southeastern Brazil, the combination of rice and beans was the only preparation that appeared weekly in the school menu for five weeks ${ }^{22}$. A household budget survey conducted by the Brazilian government during the years 2008 and 2009 shows that $84.0 \%$ of the population consumes rice and $72.8 \%$ consumes beans daily ${ }^{16}$.

The nutritional content of the preparations was calculated individually, without the addition of accompaniments like: rice, beans, bread, or meats. None of the preparations met the recommendation of at least $300 \mathrm{kcal}, 48.8 \mathrm{~g}$ of

Table 1. Nutritional composition of the regional dishes without supplements. Santos (SP), Brazil, 2010.

\begin{tabular}{|c|c|c|c|c|c|c|c|c|c|c|}
\hline & \multicolumn{10}{|c|}{ Dishes $^{*}$} \\
\hline & 1 & 2 & 3 & 4 & 5 & 6 & 7 & 8 & 9 & 10 \\
\hline Portion (g) & 121.00 & 80.00 & 135.00 & 85.00 & 98.00 & 57.00 & 35.00 & 90.00 & 410.00 & 15.00 \\
\hline Energy (kcal) & 68.02 & 138.75 & 129.45 & 183.19 & 169.14 & 90.41 & 27.60 & 58.63 & 222.42 & 21.32 \\
\hline Carbohydrates (g) & 12.29 & 29.28 & 28.69 & 43.18 & 26.61 & 15.97 & 4.00 & 1.92 & 28.06 & 5.25 \\
\hline Proteins (g) & 2.77 & 2.72 & 2.89 & 1.69 & 6.36 & 1.77 & 1.20 & 8.98 & 8.46 & 0.05 \\
\hline Lipids (g) & 0.86 & 1.20 & 0.35 & 0.41 & 4.14 & 2.16 & 0.76 & 1.67 & 8.48 & 0.01 \\
\hline Fibers (g) & 2.00 & 1.43 & 0.66 & 1.81 & 1.57 & 3.31 & 1.00 & 0.36 & 3.34 & 0.76 \\
\hline Vitamin A $(\mu \mathrm{g})$ & 84.45 & 25.68 & 26.96 & 26.20 & 58.29 & 25.51 & 278.96 & 5.46 & 239.58 & 0.01 \\
\hline Vitamin C (mg) & 4.12 & 7.63 & 4.12 & 67.69 & 8.44 & 4.73 & 38.43 & 2.19 & 78.58 & 0.15 \\
\hline Calcium (mg) & 15.19 & 23.70 & 54.28 & 36.51 & 75.67 & 12.62 & 47.17 & 16.88 & 88.66 & 2.16 \\
\hline Iron (mg) & 0.52 & 0.61 & 0.22 & 0.59 & 0.93 & 0.80 & 0.58 & 0.40 & 1.58 & 0.03 \\
\hline Magnesium (mg) & 23.63 & 7.11 & 12.79 & 37.40 & 14.10 & 23.29 & 11.32 & 13.33 & 35.16 & 1.07 \\
\hline Zinc (mg) & 0.28 & 0.23 & 0.43 & 0.40 & 0.30 & 0.38 & 0.17 & 0.29 & 0.50 & 0.02 \\
\hline
\end{tabular}

Note: *Nutritional composition of the regional dishes without accompaniments and vehicle. Dishes: 1: puréed cornmeal with spinach; 2: star fruit cake; 3: rice pudding with mango; 4: jackfruit conserve; 5: arugula pizza; 6: green beans and corn flour; 7: kale with garlic; 8: chicken with okra; 9: caldo verde soup ; 10: persimmon jelly. 
carbohydrate, $9.4 \mathrm{~g}$ of protein, and $5.4 \mathrm{~g}$ of fiber established by the Brazilian federal law for children aged 6 to 10 years in school part-time ${ }^{7}$. Therefore, it is essential to accompany these dishes with other foods, especially foods that complement their nutritional characteristics, i.e., that offer, along with the chicken with okra, a source of carbohydrate and a fruit. Of the ten study dishes, five supplied $100 \%$ of the Estimated Average Requirement (EAR) of vitamin C (ascorbic acid). Three other dishes provided at least $50 \%$ of the nutritional recommendations (Table 1).

The dishes kale with garlic and caldo verde soup provided $100.0 \%$ of the students' EAR for vitamin $A$. Both contain kale, a plant rich in $\beta$-carotene, a carotenoid with $100.0 \%$ pro-vitamin A activity. Two other dishes, puréed cornmeal with spinach and arugula pizza, provided $84.4 \%$ and $58.3 \%$, respectively, of the EAR for vitamin A.

As for minerals, all preparations but persimmon jelly met the magnesium requirement. The calcium, iron, and zinc requirements were not met by any of the preparations.

Figures 1 and 2 show the distribution of percent acceptabilities of regional dishes obtained using the methods 5-point facial hedonic scale and leftover analysis, respectively.

With regard to acceptance by analyzing the 5-point facial hedonic scale, three dishes showed acceptability rate above $85 \%$ (chicken with okra, persimmon jelly and caldo verde soup) in urban areas. In rural areas, four dishes showed these acceptability levels (puréed corn meal with spinach, arugula pizza, persimmon jelly, and caldo verde soup). Three preparations had percent acceptabilities above $90 \%$ in the leftover analysis for urban schools (kale with garlic, persimmon jelly, and caldo verde soup) and four for rural schools (star fruit cake, arugula pizza, chicken with okra, and persimmon jelly). These results differ from the ones obtained by the hedonic scale.

Consuming an entire meal, leaving no leftovers, and accepting them in terms of preferences and satisfaction are different in nature. Acceptability is a hedonic experience characterized by a definite positive attitude

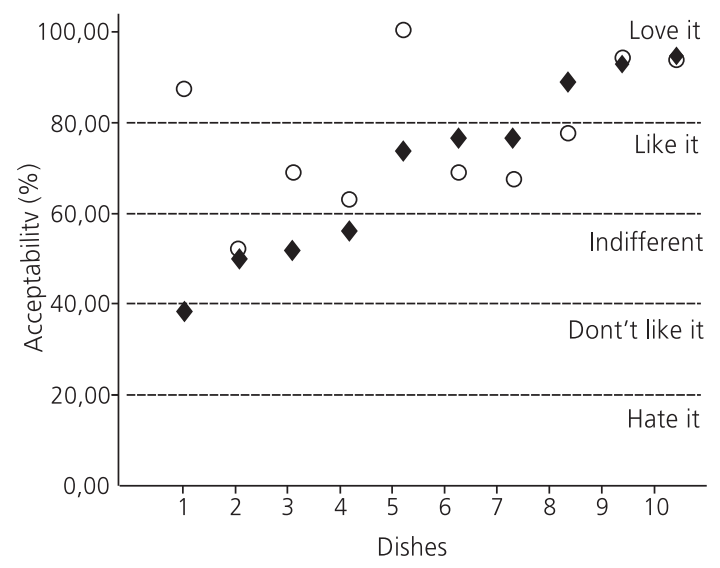

Figure 1. Acceptability rate of regional dishes tested in (") urban and (o) rural schools using the 5-point facial hedonic scale. Santos (SP), Brazil, 2010.

Note: Dishes: 1: puréed cornmeal with spinach; 2: star fruit cake; 3: rice pudding with mango; 4: jackfruit conserve; 5: arugula pizza; 6: green beans and corn flour; 7: kale with garlic; 8: chicken with okra; 9: caldo verde soup; 10: persimmon jelly.

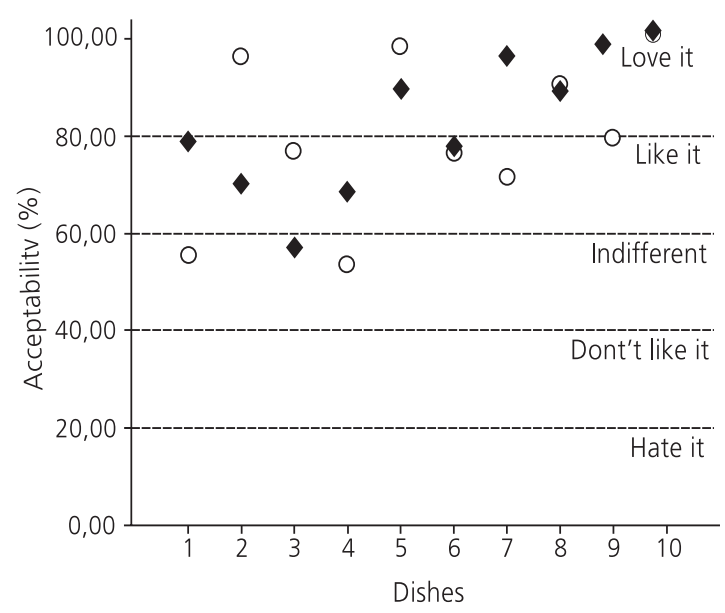

Figure 2. Acceptability rate of regional dishes tested in (") urban and (O) rural schools using leftover analysis. Santos (SP), Brazil, 2010.

Note: Dishes: 1: puréed corn meal with spinach; 2: star fruit cake; 3: rice pudding with mango; 4: jackfruit conserve; 5: arugula pizza; 6: green beans and corn flour; 7: kale with garlic; 8: chicken with okra; 9: caldo verde soup; 10: persimmon jelly. 
towards the object being analyzed and thus can be considered an affective test ${ }^{25}$. Accordingly, preparations with high acceptability rate evaluated by affective tests, but with low acceptability rate evaluated by leftover analysis (like chicken with okra in the urban schools and puréed corn meal and caldo verde soup in rural schools) can be included in the menu combined with nutrition education and strategies that reduce food waste, such as appropriate food portions, and that enhance student awareness on this issue.

The acceptabilities measured by the hedonic scale indicate that, with the exception of puréed cornmeal with spinach in urban schools, all dishes had acceptability rate above $50 \%$. Preparations with a porridge consistency, like puréed cornmeal with spinach, are generally associated with infant/elderly food by scholars or understood as a dish culturally designed for dinner ${ }^{24}$. Therefore, these preparations generally have low acceptability and low adherence index in schools, as observed in this study. The other study dishes can become part of school menus, as they were accepted or partly accepted by the students regardless of where the school was situated, whether in rural or urban areas. Acceptance, especially by children, requires time, access, and exposure to a food or preparation. The child needs to get used to the food or dish before accepting it. Thus, the percentages of acceptability can be considered reasonable, since this was the first time these dishes were offered in school meals ${ }^{25}$.

Figure 2 shows that $90 \%$ of the dishes, both in urban and rural areas, were classified as "liked" and/or "loved" according to leftover analysis. The dishes star fruit cake and rice pudding with mango were classified in rural and urban schools, respectively, as "indifferent." Leftover analysis is an indirect measure of acceptability, since it quantifies the food rejected in relation to the food served. High acceptability scores obtained by this method show not only a positive attitude towards the dishes but also little waste.

Jordanna ${ }^{26}$ defines traditional food as 'a product that must be linked to a territory, and it must also be part of a set of traditions, which will necessarily ensure its continuity over time" (p.147). Hence, regional food dishes, from the perspective of tradition, involve sociological, cultural, environmental, and not only nutritional aspects $^{27}$. The insertion (or recovery) of regional dishes in modern food systems requires recovering the self-awareness of the population ${ }^{27}$. In this direction the introduction of regional dishes during childhood can promote consumption of these dishes in the future and consequently, improve the maintenance of food culture.

The perception of those involved with this policy is another factor that can favor the inclusion of regional dishes in school food programs. Members involved with school food programs associate the rescue of regional dishes with a healthy diet ${ }^{11}$ since these dishes generally contain fruits, vegetables, and regional products, and do not use processed foods. Brazilian public policies also include the rescue of regional food habits, included in the school food program in the $1970 s^{28}$ and maintained to this day by the legislation ${ }^{5}$. This fact reinforces the program's potential as a food security policy helping Brazil to achieve the development goals for the millenium ${ }^{29}$.

Table 2 shows acceptability rate according to the hedonic scale and adherence indexes towards the regional dishes in both environments. The dishes puréed cornmeal with spinach (85.71\%) and arugula pizza (98.02\%) had higher acceptability in rural areas $(p<0.05)$, whereas in urban areas the most accepted dishes were persimmon jelly (93.33\%) and caldo verde soup (93.23\%). This difference in acceptance between students of urban and rural areas may be due to a portion of the population having greater access to some dishes. For example, the urban population has greater access to industrialized or 
processed foods than the rural population, resulting in higher household availability of these foods ${ }^{30}$. In Brazil, the consumption of pizzas is four times higher in urban areas ${ }^{16}$, and due to greater exposure to this type of dish, children from urban areas possibly show less interest towards arugula pizza, leading to greater compliance and acceptance by children from rural schools.

Significant differences were observed in the percent adherences of rural and urban schools for same-dish comparisons (Table 2). However, the region where the school was located did not influence general adherence since the adherence was higher for five dishes in urban schools and for another four dishes in rural areas. From these results it can be inferred that food adherence was not associated with a geographical factor. In both urban and rural environments, the average adherence index was $57.3 \%$ and $55.6 \%$, respectively. Other studies found lower rates of adherence in school food programs, like $23.2 \%$ in the city of Chapecó (SC) $)^{31}, 46 \%$ in the city of Piracicaba (SP) ${ }^{12}$ and $33.5 \%$ in Paraíba State ${ }^{32}$. Sturion et al. ${ }^{12}$ reported a profile characterizing the type of student that adheres to the program. This profile described them as being nutritionally compromised and coming from a family of lower income and education levels. The justification for this low adherence was attributed to poor management of the program that was conducted in a centralized manner until 1994, when the planning of menus, purchasing of groceries, quality control, and food distribution were countrywide, providing mainly processed foods, generating menu monotony, and not giving enough emphasis to cultural and regional aspects $^{4,12}$. In this context, valuing the cultural aspects of each Brazilian region can contribute significantly to school meal adherence by preparing menus that not only include fruits and vegetables, but are also part of the local dietary habit.

Table 2. Acceptability rate using the hedonic scale and adherence indexes for the regional dishes. Santos (SP), Brazil (2010).

\begin{tabular}{|c|c|c|c|c|c|c|c|c|c|c|c|}
\hline \multirow[t]{2}{*}{ Dishes } & \multirow[t]{2}{*}{ Site } & \multicolumn{2}{|c|}{ Acceptance } & \multicolumn{2}{|c|}{$\begin{array}{c}\text { Rejection/ } \\
\text { Indifference }\end{array}$} & \multirow[t]{2}{*}{$p$} & \multicolumn{2}{|c|}{$\begin{array}{l}\text { Eat/Tried } \\
\text { the dish }\end{array}$} & \multicolumn{2}{|c|}{$\begin{array}{l}\text { Did not eat/Did } \\
\text { not try the dish }\end{array}$} & \multirow[t]{2}{*}{$p$} \\
\hline & & $n$ & $\%$ & $\mathrm{n}$ & $\%$ & & $\mathrm{n}$ & $\%$ & $n$ & $\%$ & \\
\hline \multirow[t]{2}{*}{ Puréed cornmeal with spinach } & Rural & 6 & 85.71 & 1 & 14.29 & $0.03^{*}$ & 7 & 4.11 & 163 & 95.89 & $<0.001$ \\
\hline & Urban & 14 & 38.89 & 22 & 61.11 & & 36 & 44.44 & 45 & 55.56 & \\
\hline \multirow[t]{2}{*}{ Star fruit cake } & Rural & 14 & 51.85 & 13 & 48.15 & 0.91 & 27 & 19.85 & 109 & 80.15 & $<0.001$ \\
\hline & Urban & 6 & 50.00 & 6 & 50.00 & & 12 & 70.58 & 5 & 29.42 & \\
\hline \multirow[t]{2}{*}{ Rice pudding with mango } & Rural & 28 & 68.29 & 13 & 31.71 & 0.08 & 41 & 89.13 & 5 & 10.87 & $<0.001$ \\
\hline & Urban & 72 & 51.43 & 68 & 48.57 & & 140 & 44.35 & 146 & 55.65 & \\
\hline \multirow[t]{2}{*}{ Jackfruit conserve } & Rural & 10 & 62.50 & 6 & 37.50 & 0.85 & 16 & 13.55 & 102 & 86.45 & $<0.001$ \\
\hline & Urban & 29 & 55.77 & 23 & 44.23 & & 52 & 55.91 & 41 & 44.09 & \\
\hline \multirow[t]{2}{*}{ Arugula pizza } & Rural & 99 & 98.02 & 2 & 1.98 & $<0.001^{*}$ & 101 & 87.82 & 14 & 12.18 & 0.002 \\
\hline & Urban & 24 & 72.73 & 9 & 27.27 & & 33 & 66.00 & 17 & 34.00 & \\
\hline \multirow[t]{2}{*}{ Green beans and corn flour } & Rural & 64 & 68.09 & 30 & 31.91 & 0.40 & 94 & 89.52 & 11 & 10.48 & 0.390 \\
\hline & Urban & 52 & 75.36 & 17 & 24.64 & & 69 & 41.31 & 98 & 58.69 & \\
\hline \multirow[t]{2}{*}{ Kale with garlic } & Rural & 52 & 66.67 & 26 & 33.33 & 0.33 & 78 & 90.69 & 8 & 9.31 & 0.002 \\
\hline & Urban & 49 & 75.38 & 16 & 24.62 & & 65 & 26.00 & 185 & 74.00 & \\
\hline \multirow[t]{2}{*}{ Chicken with okra } & Rural & 29 & 76.32 & 9 & 23.68 & 0.24 & 38 & 52.05 & 35 & 47.95 & $<0.001$ \\
\hline & Urban & 61 & 87.14 & 9 & 12.86 & & 70 & 82.35 & 15 & 17.65 & \\
\hline \multirow[t]{2}{*}{ Caldo verde soup } & Rural & 12 & 92.31 & 1 & 7.69 & $1.00^{*}$ & 13 & 20.00 & 52 & 80.00 & $<0.001$ \\
\hline & Urban & 104 & 91.23 & 10 & 8.77 & & 114 & 44.35 & 143 & 55.65 & \\
\hline \multirow[t]{2}{*}{ Persimmon jelly } & Rural & 100 & 92.59 & 8 & 7.41 & $0.99^{*}$ & 108 & 90.00 & 12 & 10.00 & 0.390 \\
\hline & Urban & 56 & 93.33 & 4 & 6.67 & & 60 & 93.75 & 4 & 6.25 & \\
\hline
\end{tabular}

Note: *Fisher's exact test. 
An intra-class correlation coefficient of 0.77 (0.36-0.95) was observed between acceptability according to the 5-point facial hedonic scale and leftover analysis. This result indicates consistency between the methods with regard to acceptability.

Stone \& Side ${ }^{25}$ investigated the validity of sensory methods for measuring whether the results of a particular test are consistent with the facts. In this context, the present study shows the correlation between the test (5-point facial hedonic scale) and the fact (leftover analysis). Therefore, leftover analysis also proved to be an effective method for assessing the acceptability of children to the regional dishes served, although this does not have a hedonic nature, as it has been previously observed by Meiselman \& Schutz $^{33}$. The use of an ingestion test to predict the acceptability of a meal showed a positive, highly significant, correlation $(p<0.001)$ for salads, pizza and tea. The Brazilian legislation recommends both tests to evaluate acceptability in the school environment? .

Adherence also showed significant intraclass correlation with the methods of assessing acceptability, being 0.83 for the 5 -point facial hedonic scale $(p<0.01)$ and 0.64 for the leftover analysis $(p<0.05)$. This could be explained considering that children tend to eat foods they like, they know, or are used to. Thus, dishes with high adherence also showed high acceptability by both methods (5-point facial hedonic scale and leftover analysis). According to an American study, repeated exposure to food with a fruit and vegetable base increases the chance that children will want to try the dish (adherence). Over time, adherence promotes better acceptance ${ }^{25}$. This finding, similar to that obtained in our study, suggests that adherence and acceptance are correlated measures. However, new studies should be undertaken to better understand their relationship.

\section{CONCLUSION}

With the exception of puréed cornmeal with spinach, the study regional dishes presented acceptability rate above $50 \%$ as verified by different methods (affective and analytical), both in urban and rural areas. The dishes presented in this study are innovative, have fruits and vegetables in their composition, and were used for the first time in school meals. The use of regional dishes may require time, so it is important to maximize the exposure of students to these preparations associating nutrition education strategies. Thus, these preparations can possibly reach the percentage set by law, and may be part of the school menu continuously.

Analysis of the nutritional composition of the regional dishes indicates that these dishes are sources of several micronutrients, and the macronutrient composition can be consistent with the law regarding the school food program. The importance of dieticians in menu creation is noteworthy since they identify the best time to insert these dishes, considering: ingredients, seasonality, menu complexity, and nutritional composition of the other dishes.

The relationship between acceptability according to the 5-point facial hedonic scale and leftover analysis was identified. We suggest that those responsible for school food programs choose one of these two methods and analyze their results together with the adherence index. The combination of adherence index and acceptability rate can promote a greater understanding of food and dish acceptance.

Brazil is a country made up of many different nationalities and therefore, has great cultural and food diversity. The cultural heritage is an important resource for the food sovereignty of a country and should be constantly encouraged. In this sense, it is important to begin serving these dishes during childhood, contributing to the formation of healthy habits and meeting the requirements of the National School Food Program.

\section{CONTRIBUTORS}

DT CUNHA contributed to the study design, data collection, data analysis, interpretation of data 
and drafting of the manuscript; HVB GONÇALVES and AFA LIMA contributed to the data collection, data analysis and manuscript writing; PA MARTINS and VV ROSSO contributed for the study design, data analysis, manuscript writing and critical review of the manuscript; E STEDEFELDT contributed to the study design, data analysis, interpretation of data and critical review of manuscript.

\section{REFERE NCES}

1. Obelar MS, Pires MMS, Wayhs MLC. Nutrição nas fases pré-escolar e escolar. In: Welfort VRS, Lamounier JA, editores. Nutrição em pediatria: da neonatologia à adolescência. Barueri: Manole; 2009. p.55-61.

2. Borges NS, Passos EC, Stedefeldt E, de Rosso WV. Aceitabilidade e qualidade dos produtos de pescado desenvolvidos para a alimentação escolar da Baixada Santista. Alim Nutr. 2011; 22(3):441-8.

3. Santos LMP, Santos SMC, Santana LAA, Henrique FCS, Mazza RPD, Santos LAS, et al. Avaliação de políticas públicas de segurança alimentar e combate à fome no período 1995-2002: 4 - Programa Nacional de Alimentação Escolar. Cad Saúde Pública. 2007; 23(11):2681-93. doi: 10.1590/S0102-311X2 007001100016

4. Peixinho AML. A trajetória do Programa Nacional de Alimentação Escolar no período de 2003-2010: relato do gestor municipal. Ciênc Saúde Colet. 2013; 18(4):909-16. doi: 10.1590/S1413-81232 013001000002

5. Brasil. Ministério da Educação. Resolução CD/FNDE/ $n^{\circ} 26$ de 17 de junho de 2013. Dispõe sobre o atendimento da alimentação escolar aos alunos da educação básica no âmbito do Programa Nacional de Alimentação Escolar - PNAE. Diário Oficial da União. 2013 [acesso 2013 ago 21]. Disponível em: <http://www.fnde.gov.br/fnde/legislacao/ resolucoes/item/4620-resolu\%C3 \%A7\%C3\% A3o-cd-fnde-n\%C2\%BA-26,-de-17-de-junho-de2013>.

6. Souza ALC, Mamede MEO. Estudo sensorial e nutricional da merenda escolar de uma escola da cidade de Lauro de Freitas - BA. Rev Inst Adolfo Lutz. 2010; 69(2):255-60.

7. Brasil. Ministério da Educação. Fundo Nacional de Desenvolvimento da Educação Lei n 11.947 de 16 de junho 2009. Dispõe sobre o atendimento da alimentação escolar e do Programa Dinheiro Direto na Escola aos alunos da educação básica. Diário Oficial da União. 2009 [acesso 2013 ago 21].
Disponível em: <http://www.planalto.gov.br/ ccivil_03/_ato2007-2010/2009/lei/ I1 1947.htm>.

8. Brasil. Ministério da Saúde. Secretaria de Políticas de Saúde. Alimentos regionais brasileiros. Brasília: Ministério da Saúde; 2002 [acesso 2012 jun 6]. Disponível em: <http://189.28.128.100/nutricao/ docs/geral/alimentos_regionais_brasileiros.pdf>.

9. Chaves LG, Mendes PNR, Brito RR, Botelho RBA. O Programa Nacional de Alimentação Escolar como promotor de hábitos alimentares regionais. Rev Nutr. 2009; 22(6):857-66. doi: 10.1590/\$1415-52 732009000600007

10. Gabriel CG, Costa LCF, Calvo MCM, Vasconcelos FAG. Planejamento de cardápios para escolas públicas municipais: reflexão e ilustração desse processo em duas capitais brasileiras. Rev Nutr. 2012; 25(3):363-72. doi: 10.1590/S1415-527320120003 00006

11. Paiva JB, Freitas MCS, Santos LAS. Hábitos alimentares regionais no Programa Nacional de Alimentação Escolar: um estudo qualitativo em um município do sertão da Bahia, Brasil. Rev Nutr. 2012; 25(2):191-202. doi: 10.1590/S1415-52732012 000200002

12. Sturion GL, Silva MV, Ometto AMH, Furtuoso MCO, Pipitone MAP. Conditioning factors of students participation in the Brazilian school meal program. Rev Nutr. 2005; 18(2):167-81. doi: 10.1590/S141552732005000200001

13. Bartlett JE, Kotrlik JW, Higgins C. Organizational research: Determining appropriate sample size for survey research. Inf Technol Learn Perform J. 2001; 19(1):43-50.

14. Cochran WG. Sampling techniques. $3^{\text {nd }}$ ed. New York: John Wiley \& Sons; 1997.

15. Krejcie RV, Morgan DWE. Determining sample size for research activities. Educ Psychol Measurement. 1970; 30:607-10.

16. Instituto Brasileiro de Geografia e Estatística. Pesquisa de orçamentos familiares 2008-2009: análise do consumo alimentar pessoal no Brasil. Rio de Janeiro: IBGE; 2011.

17. Abreu ES, Spinelli MGN, Sousa Pinto AM. Gestão de unidades de alimentação e nutrição: um modo de fazer. $3^{a}$ ed. São Paulo: Metha; 2007.

18. Lawless HT, Heymann H. Sensory evaluation of food: Principles and practices: Acceptance and preference testing. Maryland: Aspen publishers; 1999.

19. da Cunha DT, Botelho RBA, de Brito RR, Pineli LLO, Stedefeldt E. Métodos para aplicar las pruebas de aceptación para la alimentación escolar: validación de la tarjeta lúdica. Rev Chil Nutr. 2013; 40(4):357-63. doi: 10.4067/S0717-75182013000400005 
20. Institute of Medicine, Food and Nutrition Board. Dietary reference intakes applications in dietary assessment. Washington (DC): National Academy Press; 2001.

21. Statistical Package for Social Sciences version 15.0, Chicago: SPSS; 2006.

22. Neitzke L, Molina MDB, Salaroli LB. Adequação nutricional da alimentação escolar em município rural - Espírito Santo, Brasil. Nutrire. 2012; 37(1):1-12. doi: 10.4322/nutrire.2012.001

23. Milagres RCRM, Nunes LC, Sant'Ana HMP. A deficiência de vitamina A em crianças no Brasil e no mundo. Ciênc Saúde Colet. 2007; 5(12):1253-66.

24. Freitas MCS, Minayo MCS, Ramos LB, Fontes GV, Santos LA, De Souza EC, et al. Escola: lugar de estudar e de comer. Ciênc Saúde Colet. 2013; 18(4): 979-85. doi: 10.1590/S1413-81232013000400 010

25. Stone H, Sidel JL. Test strategy and design of experiments: Sensory evaluation practices. Oxford: Elsevier Academic Press; 2004. p.99-137.

26. Jordana J. Traditional foods: Challenges facing the European food industry. Food Res Int. 2000; 33(3-4):147-52.

27. Kroon PA, D'Antuono LF. Traditional foods: from culture, ecology and diversity, to human health and potential for exploitation. J Sci Food Agric. 2013; 93(14):3403-5.

28. L' Abbate S. As políticas de alimentação e nutrição no Brasil: II a partir dos anos setentas. Rev Nutr.
1989; 2(1):7-54. doi: 10.1590/S1415-527320030 00400002

29. Câmara Interministerial de Segurança Alimentar e Nutricional. Plano Nacional de Segurança Alimentar e Nutricional: 2012/2015. Brasília: CAISAN; 2011 [acesso 2014 maio 23]. Disponível em: <http:// www.mds.gov.br/seguranca alimentar/publicacoes \%20sisan/livros/plano-nacional-de-segurancaalimentar-e-nutricional-2012-2015/LIVRO_PLANO_ NACIONAL_CAISAN_revisado,P20 SEM,P20ISBN. pdf.pagespeed.ce.ekaCWJ2LOT.pdf>.

30. Levy RB, Claro RM, Mondini L, Sichieri R, Monteiro CA. Regional and socioeconomic distribution of household food availability in Brazil, in 2008-2009. Rev Saúde Pública. 2012; 46(1):1-9. doi: 10.1590/S0 034-89102011005000088

31. Teo CRPA, Correa EM, Gallina LS, Fransozi C. Programa nacional de alimentação escolar: adesão, aceitação e condições de distribuição de alimentação na escola. Nutrire. 2009; 34(2):165-85.

32. Muniz VM, Carvalho AT. O Programa Nacional de Alimentação Escolar em município do estado da Paraíba: um estudo sob o olhar dos beneficiários do Programa. Rev Nutr. 2007; 20(3):285-96. doi: 10.1590/S1415-52732007000300007

33. Meiselman HL, Schutz HG. History of food acceptance research in the US Army. Appetite. 2003; 40(3):199-216.
Received on: 6/7/2013

Final version on: 6/5/2014

Approved on: 6/25/2014 